\title{
Financing needs and financial management practices of banana (Musa balbisiana) farmers in Inopacan, Leyte
}

\author{
Pauline S. Caintic ${ }^{1 *}$, Analita A. Salabao ${ }^{2}$ and Marlon M. Tambis ${ }^{3}$
}

\begin{abstract}
This study investigated the financing needs and the financial management practices of banana farmers in Inopacan, Leyte, the relationship between financial management practices to profitability and the relationship of the various sociodemographic variables to the relevant financial management practices. The relevant financial management practices considered in this study were those found to be significantly related to profitability. Results showed that limited capital for labor and the occurrence of pests and diseases particularly bugtok, which is caused by a bacterium called Ralstonia solanacearum, were among the major problems expressed by the banana farmers that need financing. Financial management practices such as monitoring the status of loan and financial planning and budgeting were widely practiced by the farmers. Out of the 25 farmer-respondents who availed of loan, 21 of them monitored the status of their loans. More than half of them also practiced financial planning and budgeting of their income and loan. The multiple linear regression analysis revealed that monitoring financial budgets and comparing farm profitability with that of other farms or benchmarking are significantly and positively related to profitability. The logistic regression analysis showed significant relationships of household size and being able to avail credit with the relevant financial management practices. The results imply that farmers who have more household members and who have availed of credit are more likely to monitor financial budgets and/or compare profitability with other farms.
\end{abstract}

Keywords: Banana production, Farm profitability

\footnotetext{
${ }^{1}$ Visayas Consortium for Agriculture, Aquatic and Natural Resources Program (ViCARP)

${ }^{2}$ Department of Business Management, Visayas State University, Visca, Baybay City, Leyte, 6521-A Philippines

${ }^{3}$ PhilRootcrops, Visayas State University, Visca, Baybay City, Leyte, 6521-A Philippines
}

\footnotetext{
* Corresponding Author. Address: Visayas Consortium for Agriculture, Aquatic and Natural Resources Program (ViCARP); Email: pauline.caintic@vsu.edu.ph DOI: $10.32945 /$ atr 4029.2018
} 


\section{INTRODUCTION}

The banana industry contributes significantly to the Philippine economy. The Department of Agriculture identified banana as one of its priority commodities considering the high demand for fresh and processed products both domestic and international markets.

Region 8 is focusing on the cultivation of cardaba (Musa balbisiana) banana variety to meet the regional demand particularly as a substitute for rice, banana chips processing, and processing of other products. Based on data from the Philippine Statistics Authority ([PSA] 2015), banana is one of the commonly grown crops in Leyte, with a total production of approximately 23,602 MT in an area of 4,890 hectares.

In Inopacan, a municipality of Leyte, most of the residents are dependent on farming for their livelihood and banana is one of the main agricultural crops grown. The municipality of Inopacan has a great potential for banana industry especially that its agricultural production area has the second largest share of $42.34 \%$ of the total land area (Municipal Profile 2015). However, banana farmers in Inopacan are considered as resource-poor with limited financial and physical resources.

Farmers and small entrepreneurs, as with small supply companies, need financing to allow them to expand production and/or diversify products. This financial support may include finance for inputs (such as seeds and fertilizers), production technologies (such as machinery and equipment) and marketing (such as processing, packaging and transport) (Food and Agriculture Organization [FAO] \& World Bank 2013). Agricultural financing needs to focus on identifying the financial needs of farmers for varied reasons. Interventions are deemed more likely to succeed if these are designed by taking into consideration the needs of the farmers. Farmers need financing not just for agricultural activities but also for other household needs.

Agricultural financing is very important for Inopacan farmers especially that most of the residents depend on farming for their livelihood. One of the major crops grown is banana with an average volume of $3,440 \mathrm{~kg}$ per week (MAO 2016). However, there are still many underlying problems and issues which directly affect the farmer's ability to maximize agricultural productivity. These include lack of working capital for expansion, material inputs, unavailability of labor, control of pest and diseases, and transportation of farm produce among others. Financing plays a vital role in each of these aspects so that availability of alternative solutions that would help the farmers improve their productivity and income can be determined.

Most farmers still prefer to concentrate on production rather than planning, budgeting, recordkeeping and other important financial management practices. Financial budgeting is an essential financial management and control tool because this can serve as basis for cash flow projections and need for loan. Other financial management practices that would be useful to farmers are comparing annual farm profitability to other farms or benchmarking and tracking profitability over time or trend analysis to help understand financial performance. In farming, capital acquisition is usually done through raising debt. Identifying and evaluating lenders and the financial terms of a loan are financial management practices that would be useful to farmers. At this time, we lack understanding on the financial management practices applied by farmers and the relationship of these practices to profitability. 
Financing needs and financial management practices of banana

\section{MATERIALS AND METHODS}

\section{Research Method and Locale of the Study}

The research employed a survey method. Using a questionnaire, data were gathered from three barangays of Inopacan, Leyte where most of the farmers are dependent on farming as their source of livelihood. The barangays included Cabulisan, Hinabay and Can-angay, considered as major banana producing communities of the municipality.

\section{Sampling and Data Collection}

The respondents were selected using random sampling technique. A list of the banana farmers was obtained from the barangay secretary in each of the three barangays in the study area. The banana farmers were assigned with specific numbers and respondents were selected at random by drawing lots. The real population was not really big and the actual number was not known since some farmers were not in the list. So, this study just selected a random sample with a size that was already enough to carry out statistical analysis. A minimum of 30 rule, instead of using a sample size determination formula, was being adopted. Although the study targeted more samples than the minimum required, inaccessibility in some of the identified areas during the data gathering further limited the final sample size. A total of 34 respondents were finally selected from three accessible barangays.

Aside from the survey data, the study also gathered secondary data on banana production, socio-economic and other useful information from the Municipal Agriculture Office. Also, information materials, results of related studies and publications were gathered from the Visayas State University library and from the internet.

\section{Analytical Procedure}

Descriptive and quantitative statistical tools such as totals, averages, ranks, ranges, percentages and regression analysis were used to analyze the quantitative data. With respect to data management, SPSS statistical software was used.

\section{Model Specification and Variable Definition}

To assess the relationship between financial management practices and farm profitability, multiple linear regression was used. The regression model measured the relationship of profitability to financial management practices variables. The following model was used with its specifications:

$$
\begin{aligned}
\text { Profitability }= & B_{0}+B_{1} F M-\text { Plan }+\beta_{2} F M-\text { Moni }+\beta_{3} F M-\text { Bench }+\beta_{4} F M-\text { FinPer }+ \\
& B_{5} F M-\text { Trend }+\beta_{6} F M-\text { Comp }+\beta_{7} F M-\text { Stat }+u
\end{aligned}
$$


The dependent and independent variables included in the multiple linear regression model of this study were as follows:

Dependent Variable

Profitability $=$ expressed in profit per hectare

Independent Variables

FM-Plan = a dummy variable if the respondent practiced financial planning and budgeting taking 1 for practicing and 0 for otherwise

FM-Moni = a dummy variable if the respondent practiced monitoring financial budgets taking 1 for practicing and 0 for otherwise

FM-Bench = a dummy variable if the respondent practiced comparing farm profitability with other farms (benchmarking) taking 1 for practicing and 0 for otherwise

FM-FinPer $=$ a dummy variable if the respondent practiced measuring financial performance taking 1 for practicing and 0 for otherwise

FM-Trend $=$ a dummy variable if the respondent practiced monitoring production and income over time (trend analysis) taking 1 for practicing and 0 for otherwise

FM-Comp = a dummy variable if the respondent practiced comparing interest rates and services when borrowing money from alternative sources taking 1 for practicing and 0 for otherwise

FM-Stat = a dummy variable if the respondent practiced monitoring status of loan taking 1 for practicing and 0 for otherwise

$u$

$=$ it is the error term

A logistic regression model was also used to ascertain the relationship of socio-demographic factors and other variables on the likelihood that the farmers will practice the relevant financial management practices found to be significantly associated to profitability. The combined relevant financial management practices which is dummy for practicing the relevant financial management practices, was used as the dependent variable. It was hypothesized to be related to the sociodemographic factors and other variables. The following model was used with its specifications:

\footnotetext{
Relevant FM (Probability that FM is 1$)=\beta_{0}+\beta_{1}$ Age $+\beta_{2}$ Years $+\beta_{3}$ IncOthers + $B_{4}$ IncBan $+\beta_{5}$ Loan+ $\beta_{6}$ Tenure+ $\beta_{7}$ Topo $+\beta_{8} O c c u+\beta_{9}$ Gender + $B_{10}$ CivStat $+\beta_{11}$ ExSupp $+u$
} 
Financing needs and financial management practices of banana

Where:


management practices taking 1 for practicing and 0 for not practicing

$\begin{array}{ll}\begin{array}{ll}\text { Age } \\ \text { Years }\end{array} & \text { actual age of the respondent in years } \\ \text { IncOthers }= & \text { actual years in farming } \\ \text { IncBan } & \text { measures the annual income from other sources } \\ \text { Loan } & \text { measures the annual net income from banana } \\ = & \text { a dummy variable for being able to avail loan taking } 1 \text { for availed } \\ & \text { and } 0 \text { for not availed } \\ = & \text { a dummy variable for the tenure taking } 1 \text { for owner and } 0 \text { for } \\ & \text { otherwise } \\ = & \text { a dummy variable for topography of the farm taking } 1 \text { for plain } \\ & \text { and } 0 \text { for otherwise } \\ \text { Topo } & \text { a dummy variable for major occupation taking } 1 \text { for farming and } \\ & \text { o for otherwise } \\ = & \text { a dummy variable for gender of the respondent taking } 1 \text { for male } \\ \text { Occu } & \text { and } 0 \text { for female } \\ \text { Gender } & \text { a dummy variable for civil status of the respondent taking } 1 \text { for } \\ & \text { married and } 0 \text { for otherwise } \\ \text { CivStat } & \text { a dummy variable for being able to receive external support } \\ & \text { taking } 1 \text { for received and } 0 \text { for otherwise } \\ \text { ExSupp } & \text { it is the error term }\end{array}$

The models were subjected to various diagnostic tests to meet the necessary assumptions for regressions such as linearity (for linear regression), normality, homoscedasticity, no multicollinearity, independent residuals and constant variance. A known outlier was removed to eliminate influential cases bias.

For the logistic regression, some of the variables that have caused errors in the model were also removed in the final model especially that this study only used relatively few samples. The least important and erroneous variables were eliminated based on their weights, variability and stability in the regression. The final result is presented in Table 10.

\section{RESULTS AND DISCUSSION}

\section{Socio-demographic characteristics of the Banana Farmers}

Thirty-four banana farmers from three selected barangays of Inopacan, Leyte served as respondents of this study. There were 21 respondents from Brgy. Cabulisan, eight from Brgy. Hinabay, and five from Brgy. Can-angay (Table 1). Results revealed that the average age of the respondents was 56.85 years old ranging from 27 to 77 years old. Majority of the respondents were female $(70.6 \%)$. Out of 34 respondents, 31 were married, two were single and only one was a widow. In terms of household size, the respondents had an average household size of 3.65 members. 
The major occupation of the respondents was farming (97.1\%) with an average farming experience of 17 years. Average monthly income of the farmers was $\mathrm{PhP} 8,021.00$. of which $39.72 \%$ of the total income came from banana production while another $60.28 \%$ came from other sources of income such as wages, salaries, and remittances.

1 US\$1 is equivalent to PhP53)

Table 1. Socio-demographic profile of the respondents



\section{Characteristics of the Banana Farms}

Table 2 describes the characteristics of the banana farms in the area. The average farm size of the respondents was $1.96 \mathrm{ha}$ and the average farm size for banana farm alone was $0.78 \mathrm{ha}$. Data revealed that out of 34 farmers, 26 of them reported that they owned the land they were farming, five served as tenants, and only three were part-owners. 
Financing needs and financial management practices of banana

Table 2. Description of the banana farms of the respondents

\begin{tabular}{|c|c|c|c|}
\hline Item & Number & & Percentage (\%) \\
\hline Average farm area & & 1.96has & \\
\hline $\begin{array}{l}\text { Average area planted to } \\
\text { banana }\end{array}$ & & 0.78ha & \\
\hline \multicolumn{4}{|l|}{ Tenure } \\
\hline Owner & 26 & & 76.5 \\
\hline Part-owner & 3 & & 8.8 \\
\hline Share tenant & 5 & & 14.7 \\
\hline Total & 34 & & 100.0 \\
\hline \multicolumn{4}{|l|}{ Topography } \\
\hline Plain/flat & 5 & & 14.7 \\
\hline Rolling & 15 & & 44.1 \\
\hline Hilly & 13 & & 38.2 \\
\hline Mountainous & 1 & & 2.9 \\
\hline Total & 34 & & 100.0 \\
\hline
\end{tabular}

Topography of the banana farms ranged from flat areas to mountainous areas. Flat areas were usually located at residential areas near the central part of the communities where $14.7 \%$ of the farms were located. Many of the farms were located in the rolling areas (44.1\%). Generally, hilly areas had a higher slope than that of rolling areas where $38.2 \%$ of the farms were located. Only $2.9 \%$ of the farms were located in the mountainous areas.

\section{Production, Productivity and Profitability}

Harvesting of banana was done by majority of the farmers at two weeks interval or twice a month (58.8\%) while $32.4 \%$ of the respondents harvested their banana weekly. Only $8.8 \%$ of the respondents did the harvesting once a month.

Table 3 presents the production, productivity, and the annual farm income analysis of the banana farmers' production in Inopacan, Leyte. The average volume of banana production was $3,631.76 \mathrm{~kg} / \mathrm{farm}$ and $7,464.7 \mathrm{~kg} / \mathrm{ha} / \mathrm{year}$. This volume of production is relatively small compared to the total volume of banana traded per week in Inopacan, which is about 4,360kg according to the Municipal Agriculture Office. 
Caintic, Salabao \& Tambis

Table 3. Annual production, productivity and net income analysis of the banana farmers' production in Inopacan, Leyte

\begin{tabular}{lrr}
\hline \multicolumn{1}{c}{ Item } & \multicolumn{1}{c}{ Per Farm } & Per Hectare \\
\hline Annual production (kg) & $3,631.76 \mathrm{~kg}$ & \\
Annual productivity (yield/ha) & & $7,464.71 \mathrm{~kg}$ \\
Annual Gross Income ${ }^{\prime /}$ & $\mathrm{P} 38,241.17$ & $\mathrm{P} 58,004.14$ \\
Expenses & & \\
$\quad$ Labor for land preparation & 229.41 & 458.82 \\
$\quad$ Labor for planting & 17.65 & 35.29 \\
$\quad$ Labor for underbrushing & $3,208.82$ & $4,757.33$ \\
$\quad$ Labor for desuckering & 41.18 & 16.74 \\
$\quad$ Labor for harvesting & $2,089.41$ & $3,251.49$ \\
$\quad$ Labor for packing & 423.53 & 130.31 \\
$\quad$ Labor for marketing & 520.59 & 855.20 \\
\hline$\quad$ & 138.24 & 182.98 \\
$\quad$ Packing materials & 936.53 & $1,516.09$ \\
$\quad$ Transportation & & $11,204.25$ \\
Total Cash Expenses & $7,605.36$ & \\
\hline Annual Net Income Above Cash Cost & $30,635.81$ & $46,799.89$ \\
\hline 1/ Annual production x P 10.53 & &
\end{tabular}

The annual cash income was derived from the value of the banana sold. Cash cost incurred were labor for land preparation, planting, underbrushing, desuckering, harvesting, packing, and handling during marketing. The highest labor expenses incurred was for underbrushing which constituted $49.13 \%$ followed by labor expenses for harvesting which was $31.99 \%$ of the total labor expenses. The lowest expenses incurred was labor for planting. Total cost of labor per farm was P6,530.59 which was $85.87 \%$ of the total production cost. Family labor was not accounted for in the net income analysis because it was very difficult to account due to the very informal nature of banana family labor in the area. Some activities were just done alongside with the other farming activities. Family labor was also considered minimal due to its association with other farm activities. This study, therefore, concentrated only on cash costs and income. Other costs incurred were packing materials and transportation. The transportation expenses were only minimal considering that most of the buyers usually come to the barangay to buy the harvested bananas. The farmer-respondents did not have any expenses in terms of material inputs. The farmers would only get planting materials from the existing crops while inputs supply such as fertilizers, pesticides were not used by the farmers in their banana production.

The respondents had an annual average gross income per farm of $\mathrm{PhP} 38,241.17$ and PhP58,004.14 per hectare. The total expenses per farm was $\mathrm{PhP7}, 605.36$ and PhP11,204.25/hectare. The annual net income above cash cost was PhP30,635.81 and PhP46,799.89/farm and per hectare, respectively.

\section{Financing Needs of the Banana Farmers}

Banana farmers in Inopacan are considered small and marginal farmers. This is evident in their landholdings of which average farm area was only $1.96 \mathrm{ha}, 0.78 \mathrm{ha}$ 
of which was devoted to banana with an annual productivity estimated at $7,464.71 \mathrm{~kg} / \mathrm{ha}$.

Due to small holdings, low productivity, and small income, financing is essential to help the farmers maximize productivity. Table 4 presents the different issues and problems in banana production where farmers may need financing. Among the issues and problems, limited capital for labor was identified by $94.1 \%$ of the farmers. It is important to note that $85.87 \%$ of the total cost of production was accounted for labor costs.

Another problem identified in banana production that needs financing was the limited capital for expansion which was expressed by $79.4 \%$ of the farmers. The financial need on capital for labor and farm expansion can be justified due to the fact that total land area of the farmers is not fully utilized. Results of the study suggest that financing plays a vital role for the payment of labor to enable them to expand their area of production. As mentioned by Ahmed (2012), a major obstacle in expanding and realizing the potential of crops is the high cost of establishing new plantations.

Occurrence of pests and diseases was identified by $44.1 \%$ of the farmers as a problem that need financing. During the conduct of the survey, some of the farmers mentioned that they lack technical knowledge on how to solve bugtok in banana, a disease caused by a bacterium called Ralstonia solanacearum. This result showing that bugtok affects banana yield is consistent with the findings of Bales et al (2014).

Table 4. Financing needs of banana production identified by the respondents

\begin{tabular}{lcc}
\hline \multicolumn{1}{c}{$\begin{array}{c}\text { Problems and Issues that } \\
\text { needs Financing * }\end{array}$} & Number & $\begin{array}{c}\text { Percentage } \\
(\%)\end{array}$ \\
\hline Limited capital for labor & 32 & 94.1 \\
Limited capital for expansion & 27 & 79.4 \\
Lack of capital for pest and disease control & 15 & 44.1 \\
Limited capital for material inputs & 4 & 11.8 \\
Lack of Equipment & 4 & 11.8 \\
Lack of storage facilities & 4 & 11.8 \\
Inadequate infrastructure (farm-to-market & 3 & 8.8 \\
roads, post-harvest facilities, etc.) & & \\
Inadequate transportation facilities & 3 & 8.8 \\
\hline
\end{tabular}

* Multiple response

\section{Access to Credit or Loan of the Banana Farmers}

Table 5 presents the number of banana farmers who availed of credit or loan, the sources of loan, and the terms and conditions associated in availing the loaned amount. 
Caintic, Salabao \& Tambis

Table 5. Number and percentages of banana farmers who availed loan, sources of loan and the terms and conditions in availing of loan

\begin{tabular}{|c|c|c|}
\hline Item & Number & Percentage (\%) \\
\hline \multicolumn{3}{|l|}{ Availed credit/loan } \\
\hline Yes & 25 & 73.5 \\
\hline No & 9 & 26.5 \\
\hline Total & 34 & 100.0 \\
\hline \multicolumn{3}{|l|}{ Source } \\
\hline Businessmen & 4 & 16.0 \\
\hline Microfinance & 21 & 84.0 \\
\hline Total & 25 & 100.0 \\
\hline $\begin{array}{l}\text { Average amount } \\
\text { borrowed }\end{array}$ & & P 8,080.00 \\
\hline Interest rate & & $2.5 \%$ to $3.5 \%$ \\
\hline Maturity & & 3 to 6 months \\
\hline
\end{tabular}

Twenty-five out of 34 farmer-respondents reported that they have availed of credit or loan while the other nine did not. While farmers can avail loans from various sources, microfinance such as Dungganon, Ramon Aboitiz Foundation Incorporated, Center for Agriculture and Rural Development, Association for Social Advancement, Islamic Co-operative Finance Australia Limited and Taytay Sa Kauswagan, Inc. constitute as major sources where $84 \%$ of the respondents availed their loan. The other $16 \%$ of the respondents availed their loan from businessmen. These different sources generally lend money for short periods that ranged from three to six months with an interest rate that ranged between $2.5 \%$ up to $3.5 \%$.

\section{External Support to Banana Farmers}

Table 6 presents the external support received by farmers from different institutions in various forms. Almost all farmers (97\%) received assistance from different institutions. From among those who received external support, only three of them received assistance for banana production. Twenty-seven farmers received assistance from government agencies such as the Philippine Coconut Authority, Department of Social Welfare and Development, Department of Agrarian Reform, and South East Asian Regional Center for Graduate Studies and Agricultural Research while another 15 farmers received assistance from the provincial and local governments units. Only three farmers received assistance from private institutions such as EastWest Seed Company wherein farmers availed of inputs supply in a form of loan payable after harvest. Most of the farmers $(70.59 \%)$ received assistance in a form of inputs supply while many $(38.24 \%)$ received financial assistance. Only very few $(9.1 \%)$ of the farmers received assistance for banana production while almost all of the respondents (90.9\%) received assistance intended for the other crops that they grow like coconut and vegetables. 
Financing needs and financial management practices of banana

Table 6. Number and percentages of farmers who availed assistance, purpose of assistance, sources of assistance, and form of assistance availed by farmers

\begin{tabular}{lrr}
\multicolumn{1}{c}{ Item } & Number & $\begin{array}{r}\text { Percentage } \\
(\%)\end{array}$ \\
\hline Received assistance from external sources & 33 & 97.1 \\
Yes & 1 & 2.9 \\
No & 34 & 100.0 \\
Total & & \\
& & \\
Source* & 27 & 79.41 \\
$\quad$ National Government Agencies (NGAs) & 15 & 44.12 \\
Local Government Unit (LGU) & 3 & 8.82 \\
Private institution & & \\
& & \\
Kind of assistance* & 3 & 5.82 \\
$\quad$ Technical assistance & 2 & 38.24 \\
Provision of credit & 13 & 70.59 \\
\hline Financial assistance & 24 & 35.29 \\
Supply inputs & 12 & \\
Others & & 9.1 \\
& & 90.9 \\
Purpose of assistance & 3 & 100.0 \\
$\quad$ For banana production & 30 & \\
For other crops/purpose & 33 & \\
Total & & \\
\hline
\end{tabular}

\section{Financial Management Practices of the Banana Farmers}

Table 7 shows the financial management practices of banana farmers. Results indicate that a great number of farmers monitor the status of their loan (84.0\%). Also, more than half of the total respondents were preparing financial plan and budget of their loan $(60.0 \%)$ and income (58.8\%). When it comes to borrowing money from different sources, the most basic evaluation technique is to compare rates and services from across sources.

Table 7. Financial management practices done by farmers

\begin{tabular}{|c|c|c|}
\hline Item & Number & $\begin{array}{c}\text { Percentage } \\
(\%)\end{array}$ \\
\hline $\begin{array}{l}\text { Monitor status of loan (payment made, remaining } \\
\text { balance) }\end{array}$ & 21 & 84.0 \\
\hline Financial planning and budgeting of loan & 15 & 60.0 \\
\hline Financial planning and budgeting of income & 20 & 58.8 \\
\hline $\begin{array}{l}\text { Compare interest rates (and services) when } \\
\text { borrowing money from alternative sources }\end{array}$ & 9 & 36.0 \\
\hline Monitor financial budgets & 7 & 20.6 \\
\hline $\begin{array}{l}\text { Compare farm profitability to other farms } \\
\text { (benchmarking) }\end{array}$ & 7 & 20.6 \\
\hline $\begin{array}{l}\text { Monitor production and income over time (trend } \\
\text { analysis) }\end{array}$ & 6 & 17.6 \\
\hline Measures financial performance (net income) & 5 & 14.7 \\
\hline
\end{tabular}


However, only some of the farmers (36.0\%) indicated they compare interest rates and services offered by the different sources. This proportion is rather small considering that majority of the farmers $(73.5 \%)$ borrowed money or availed of loans. The farmer-borrowers may not be aware of the benefits of this simple financial management practice that will enable them to take advantage of the power of competitive markets. Also, the farmers may have the perception that all sources of credit offered the same services and charged the same rates.

With respect to monitoring the status of a loan, most of the respondents $(84.0 \%)$ indicated that they monitor their loans in terms of payment being made and remaining balance. While this response rate may appear to be exceptionally high, it is important to note that most of the microfinancing institutions are providing their borrowers with a passbook that reflects their loan transactions and served as reference for the farmers.

More than half $(58.8 \%)$ of the respondents prepared financial plans and budgeted their income. Of the farmers who availed of loans, $60.0 \%$ of them prepared financial plans and budget. The results suggest that farmers who availed of loans felt the importance of a financial budget as it allows them to assess their repayment capacity.

Table 8 presents how the respondents planned and budgeted their income and loan. For those who responded that they did financial planning and budgeting of their income, $44.1 \%$ allocated a portion of their income for banana production such as labor. More than half of the respondents $(58.8 \%)$, allocated a portion of their income for food consumption while some of the respondents have allocated a portion of their income for other purposes such as education $(32.4 \%)$ and health $(26.5 \%)$. With the limited income, the family would have a problem in allocating funds for both household use and farm activities. This is because farm business and the farm household compete for funds in the same manner as do competitive enterprises (Nelson et al 1973).

From among those who prepared financial planning and budgeting of their loan, results showed that $46.7 \%$ of the respondents have allocated their loaned amount for various purposes such as labor for banana production, farm use and activities related to other crops, and for food consumption. Also, some of the respondents $(20 \%)$ have allocated their loaned amount for education, health and other non-farm use. These findings confirmed the study of Lambert (2000) showing that farmers utilized their credit to finance for their farm production and for home use or consumption. This implies that loan or credit of farmers is utilized both for farm use and also for other financial requirements of the family. 
Financing needs and financial management practices of banana

Table 8. Number and percentage of farmers who prepared financial plan and budget, and the financial planning and budgeting of their income and loan

\begin{tabular}{|c|c|c|c|c|}
\hline \multirow[t]{2}{*}{ Item * } & \multicolumn{2}{|c|}{ Income } & \multicolumn{2}{|c|}{ Loan } \\
\hline & Number & $\begin{array}{c}\text { Percentage } \\
(\%)\end{array}$ & Number & $\begin{array}{c}\text { Percentage } \\
(\%)\end{array}$ \\
\hline \multicolumn{5}{|c|}{ Preparation of financial plan and budget } \\
\hline Yes & 20 & 58.8 & 15 & 60.0 \\
\hline No & 14 & 41.2 & 10 & 40.0 \\
\hline Total & 34 & 100.0 & 25 & 100.0 \\
\hline \multicolumn{5}{|l|}{$\begin{array}{l}\text { Financil plan and budget } \\
\text { Farm Use (Banana } \\
\text { production) }\end{array}$} \\
\hline Labor & 15 & 44.1 & 7 & 46.7 \\
\hline Fertilizer & 0 & 0 & 1 & 6.7 \\
\hline Pesticides & 0 & 0 & 0 & 0 \\
\hline Planting materials & 1 & 2.9 & 0 & 0 \\
\hline Bagging materials & 0 & 0 & 0 & 0 \\
\hline Packaging materials & 4 & 11.8 & 0 & 0 \\
\hline $\begin{array}{l}\text { Transportation/Vehicle } \\
\text { rental }\end{array}$ & 4 & 11.8 & 2 & 13.3 \\
\hline Farm Use (Other crops) & 6 & 17.6 & 7 & 46.7 \\
\hline \multicolumn{5}{|l|}{ Non-Farm Use } \\
\hline Education & 11 & 32.4 & 3 & 20.0 \\
\hline Health & 9 & 26.5 & 3 & 20.0 \\
\hline Food & 20 & 58.8 & 7 & 46.7 \\
\hline Socialization & 2 & 5.9 & 1 & 6.7 \\
\hline Appliances & 4 & 11.8 & 1 & 6.7 \\
\hline House repair & 1 & 2.9 & 0 & 0 \\
\hline Others, specify & 2 & 5.9 & 3 & 20.0 \\
\hline
\end{tabular}

\section{Financial Management Practices and Profitability of Banana Farmers}

The data presented in Table 6 only show the ranking of the financial management practices applied by farmers but do not identify which among them were really relevant to profitability. This section presents an analysis investigating the relationship between the financial management practices and farm profitability using multiple linear regression. The purpose is to identify the financial management practices that are associated to profitability. This also narrows down the list of the financial management practices to be included in the analysis for the factors associated to financial management practices. Only the relevant financial management practices, as analyzed in the regression, will be subjected to relationship analysis (logistic regression) with the socio-demographic and other variables hypothesized to be associated with financial management practices.

Table 9 shows that among the financial management practices, only the monitoring of financial budgets and comparing farm profitability with other farms or benchmarking had positive and significant relationships with farm profitability. 
These findings suggest that farmers who monitor financial budgets also have good financial performance. This is because effective financial management starts with keeping records such as monitoring of financial budgets. This best practice will help farmers make meaningful decisions about banana production and other endeavors. Results of the study support the findings of Onduso (2013) which revealed that there is a strong positive effect of budgeting on the financial performance as measured by return on assets.

Table 9. Estimated multiple linear regression coefficient of the variables affecting profitability of banana production

\begin{tabular}{lccc}
\hline \multicolumn{1}{c}{ Variable } & Coefficients & \multicolumn{1}{c}{ T-Value } & P-Value \\
\hline Constant & 25172.98 & 1.037 & 0.309 \\
Financial planning and budgeting & -32678.57 & -0.966 & 0.343 \\
Monitoring financial budgets & 137860.86 & 3.008 & $0.006^{\text {** }}$ \\
Comparing farm profitability with other & 71350.27 & 1.756 & $0.091^{*}$ \\
farms (benchmarking) & & & \\
Measuring financial performance & -56685.67 & -0.929 & 0.362 \\
Monitoring production and income over & -50573.07 & -1.068 & 0.295 \\
time (trend analysis) & & & \\
Comparing interest rates & 32321.60 & 0.898 & 0.377 \\
Monitoring loan status & 4269.79 & 0.135 & 0.893 \\
\hline
\end{tabular}

$\mathrm{R}^{2}=67.4 \%(0.674)$

$*$ * $=$ significant at $1 \%$

* $=$ significant at $10 \%$

Results of the analysis also showed that benchmarking or comparing the farm's financial performance with that of other farms had a significant positive effect to profitability. This means that farmers who compare farm financial performance with other farmers are more profitable in their business. This finding supports the claim of Kahan (2010) that benchmarking can lead to increased profitability and improved efficiency in the farm business. Ronan (2000) also stated that benchmarking can aid in the pursuit of productivity and profits by farmers through richer information about enterprise performance and can provide a catchment of ideas for continuous improvement.

\section{Factors Associated to Financial Management Practices}

A logistic regression was performed to ascertain the relationship of sociodemographic and other variables like age of respondent, years in farming, income, able to avail loan, tenure, topography, occupation, gender, civil status and access to external support on the likelihood that the farmers will practice the relevant financial management practices. All the hypothesized variables cannot be included into a single model due to sample size limitation so several iterations were done to select the relevant set of independent variables to explain the dependent variable which is the combination of monitoring financial budgets and benchmarking. The two were significantly and positively related to profitability based on the regression analysis. The dependent variable is a dummy, with a value of 1 if a respondent is practicing either of the two relevant variables or both and value of 0 if not. The final model (Table 10) was statistically significant, $x^{2}=10.718$, P-value $<0.10$. The model explained $38.5 \%$ (Nagelkerke $r^{2}$ ) of the variation in the dependent variable and 
correctly classified $85.3 \%$ of cases. Based on the result, household size and being able to avail loan appear to be significantly associated with the combined relevant financial management practices. An increase in household size will increase the likelihood by 1.658 times that the farmers will practice the relevant financial management practices. This is due to the fact that the banana enterprises in the study area are mainly family enterprises and so more household members would mean more manpower to do any activities related to banana production including the relevant financial management practices. The result also suggests that if the farmers have availed of credit or loan, they are about 14 times more likely to perform the relevant financial management practices. It is simply because the banana farmers in the study area are relatively poor and without the help of the finances they get from credit, they only have limited funds to manage. By being able to avail credit, this will give them more flexibility with finances and can allocate a portion of the money for banana production. Having some funds to allocate for banana can make the banana enterprise more profitable as banana production needs some financing for inputs first before it can give some returns.

Table 10. Estimated logistic regression coefficient of the variables affecting financial management practices

\begin{tabular}{lcc}
\hline \multicolumn{1}{c}{ Variable } & P-Value & Odds Ratio \\
\hline Household size & 0.063 & $1.658^{*}$ \\
Age of respondent & 0.232 & 0.941 \\
Tenure & 0.236 & 5.581 \\
Topography & 0.236 & 6.260 \\
Able to avail credit or loan & 0.073 & $14.091^{*}$ \\
Constant & 0.346 & 0.038 \\
\hline $\mathrm{R}^{2}=38.5 \%$ & & \\
${ }^{*}=$ significant at $10 \%$ & &
\end{tabular}

\section{IMPLICATION AND RECOMMENDATIONS}

For an enhanced productivity of banana, government agencies and other organizations should take steps in helping farmers by providing them with their financing needs in terms of the lack of capital for labor and farm expansion and also the lack of capital for the control of pests and diseases. Based on the results of the study, only very few of the respondents received assistance for banana production. There is also a need to strengthen extension support services by conducting training workshops for the farmers, provision of disease-free planting materials and technical assistance. Conducting training on the appropriate production technologies will improve farmers' practices and the problem on bugtok disease infestation will be addressed.

The result of the logistic regression analysis which shows significant relationship of being able to avail of loan with the combined relevant financial management practices, can be used as the basis for possible financing interventions to address the financing needs of the farmers. Financing programs and interventions could be in a form of credit as this was found to have significant relationship to the relevant financial management practices or the practices that showed positive and significant relationship to profitability. 
Mores studies may be conducted to identify the specific scheme by which provision of credit as a financing intervention can be extended or provided to the farmers. The specific scheme could also come from experts who will implement the intervention.

Certain financial management practices that showed positive relationships on profitability can then be used as basis to prioritize educational offerings and also in the conduct of capability building activities. Training workshops need to be conducted to capacitate the farmers on the appropriate financial management practices. Farmers will be trained to provide them with adequate knowledge in monitoring financial budgets and comparing farm profitability to other farms or benchmarking as these are important financial management tools found to enhance their financial capabilities and competitiveness.

The results regarding the association of some of the financial management practices on profitability and the results on the relationship of household size and being able to avail of credit with the relevant financial management practices are only preliminary. While this study has explored the relationships between financial management practices and profitability, further work is needed to examine other factors that could also influence the conduct of relevant financial management practices. Certain financial management practices can impact on profitability. Further study focusing on financial management practices' relationship with sociodemographic factors not covered in this study can also be conducted. Also, to further improve this kind of analysis, this study recommends that future studies be conducted with a larger sample size. There are some limitations that arise in studying relationships with only a small sample size as experienced in this study.

\section{REFERENCES}

Ahmed EA, Faki HHM \& Hussein A. 2012. Role of Agricultural Finance in Producing Food Crops. International Journal of Agriculture and Forestry, 2(2):10-15

Bales et al. 2014. Participatory Assessment of Resources and Needs of Upland Communities: A Case in Inopacan, Leyte, Philippines. Annals of Tropical Research, 36[Supplement]:259-277

FAO \& World Bank. 2013. Financing smallholder agricultural term investments. Retrieved fromhttp://www.ruralfinance.org/fileadmin/templ ates/rflc/documents/6_financing_smallholder_web.pdf

Kahan D. 2010. Farm Business Analysis using benchmarking. E-ISBN 978-92-5107546-3 (PDF) @ FAO 2013

Lambert AGP. 2000. Factors Affecting Productivity of Coconut Farmers in Mahaplay, Leyte. Unpublished Undergraduate Thesis. Visayas State University, Visca, Baybay City, Leyte

Municipal Agriculture Office. 2016. Municipality of Inopacan, Leyte

Municipal Profile. 2015. Municipality of Inopacan, Leyte

Nelson AG et al. 1973. Agricultural Finance (6th edn). The lowa State University, AMES. ISBN 0-8138-0050-1

Onduso EO. 2013. The effect of budgets on financial performance of manufacturing companies in Nairobi County (MS Thesis). University of Nairobi, Kenya 
Financing needs and financial management practices of banana

Philippine Statistics Authority. 2015. Other Crops/Production/ CountrySTATPhilippines. http://countrystat.psa.gov.ph/selection.asp

Ronan G and Cleary G. 2000. Best practice benchmarking in Australian agriculture: issues and challenges. Agribusiness Perspectives-Paper 39 